Article

\title{
Alkaloids Induce Programmed Cell Death in Bloodstream Forms of Trypanosomes (Trypanosoma b. brucei)
}

\author{
Vera Rosenkranz and Michael Wink * \\ Heidelberg University, Institute of Pharmacy and Molecular Biotechnology. INF 364, 69120 \\ Heidelberg, Germany
}

* Author to whom correspondence should be addressed; E-mail: wink@uni-hd.de.

Received: 30 June 2008; in revised form: 5 September 2008 / Accepted: 30 September 2008 / Published: 3 October 2008

\begin{abstract}
The potential induction of a programmed cell death (PCD) in Trypanosoma $b$. brucei by 55 alkaloids of the quinoline, quinolizidine, isoquinoline, indole, terpene, tropane, steroid, and piperidine type was studied by measuring DNA fragmentation and changes in mitochondrial membrane potential. For comparison, the induction of apoptosis by the same alkaloids in human leukemia cells (Jurkat APO-S) was tested. Several alkaloids of the isoquinoline, quinoline, indole and steroidal type (berberine, chelerythrine, emetine, sanguinarine, quinine, ajmalicine, ergotamine, harmine, vinblastine, vincristine, colchicine, chaconine, demissidine and veratridine) induced programmed cell death, whereas quinolizidine, tropane, terpene and piperidine alkaloids were mostly inactive. Effective PCD induction ( $\mathrm{EC}_{50}$ below $10 \mu \mathrm{M}$ ) was caused in $T$. brucei by chelerythrine, emetine, sanguinarine, and chaconine. The active alkaloids can be characterized by their general property to inhibit protein biosynthesis, to intercalate DNA, to disturb membrane fluidity or to inhibit microtubule formation.
\end{abstract}

Keywords: Trypanosomiasis, leukemia, Trypanosoma brucei, Jurkat APO-S, alkaloids, apoptosis, programmed cell death 


\section{Introduction}

Trypanosomes (family Trypanosomatidae, order Kinetoplastida) are unicellular flagellates. African trypanosomes are important as parasitic protozoa of humans and animals. Trypanosoma brucei causes sleeping sickness in humans, whereas $T$. congolense is the causative agent responsible for Nagana (animal African trypanosomiasis) in cattle. Trypanosomes have a complicated life cycle, living and multiplying freely in the blood and tissue fluids of their mammalian hosts. Trypanosomes are transmitted by Tsetse flies (genus Glossina), in which they undergo another developmental cycle. In Africa, over 50 million people live in areas with tsetse flies and trypanosomes. About 25,000 to 50,000 new infections of sleeping sickness are reported annually [1]. Nagana is a potential threat for 46 million cattle and it causes damage of about US \$1,340 million per year [2]. If left untreated, trypanosome infections are fatal. Unfortunately, no vaccine is available against trypanosomes and chemotherapy still relies on drugs that were developed decades ago. Some of the drugs exhibit substantial toxic side effects [3]. Furthermore, drug resistance has been reported from animals [4]. Therefore, it is important to search for new drug candidates to treat sleeping sickness.

In an earlier publication we had analysed the cytotoxic potential of 34 alkaloids of various structural types against T. brucei and T. congolense [5]. Berbamine, berberine, cinchonidine, cinchonine, emetine, ergotamine, quinidine, quinine, and sanguinarine exhibited trypanocidal activities with $\mathrm{ED}_{50}$ values lower than $10 \mu \mathrm{M}$. These activities are similar to those of the antitrypanosomal drugs suramin and diminazene aceturate. The alkaloids also showed cytotoxicity against human HL60 cells [5]. In another study we could show that cell death in HL60 cells is due to apoptosis [6].

Many alkaloids, of which more than 21,000 structures have been found in plants, show a high degree of toxicity towards animals. Whereas many alkaloids are neurotoxins that interfere with neuroreceptors, ion channels or other parts of the neuronal signal chain, a substantial number of alkaloids are cytotoxic. Cytotoxicity is a result of the molecular interactions of an alkaloid with one or several important targets present in a cell. The main targets include DNA, RNA, and the associated enzymes and processes (i.e., replication, repair, transcription, DNA polymerase, RNA polymerase, reverse transcriptase, repair enzymes, topoisomerase, telomerase), protein biosynthesis, protein conformation, biomembrane integrity, and membrane proteins [for reviews see 7-11].

Cell biologists distinguish between necrotic and apoptotic cell death. If a cell is lysed by saponins or other detergents, or when it is mechanically wounded or exposed to physical stress (heat, freezing, hypoxia), then it dies quickly by necrosis and often causing an inflammation. Apoptosis or programmed cell death, that was discovered about 35 years ago in 1972 by Kerr, Wyllie, and Currie [12], is a central mechanism in the development of most organisms. Apoptosis is characterized by nuclear chromatin condensation, cytoplasmic shrinking, dilatation of endoplasmic reticulum, membrane blebbing, and the formation of apoptotic bodies. Programmed cell death does not cause inflammation as cells are digested by macrophages or neighboring cells. Apoptosis can be induced by many substances, among them several natural products, such as several alkaloids, polyphenols, terpenoids, or saponins that primarily interact with an important molecular target such as DNA, microtubules, biomembranes and receptors. Most of the anticancer drugs presently used in cancer therapy induce apoptosis $[6,10]$. 
Apoptosis can be induced by two pathways: the extrinsic pathway starts with an activation of death receptors on the cell surface, which leads to the activation of caspases. The intrinsic pathway is triggered by the permeabilization of mitochondrial membranes, furthermore by releasing cytochrome $\mathrm{c}$ and reducing ATP levels [13]. Cytochrome $\mathrm{c}$ and other apoptotic factors lead to the activation of caspase 9, which finally activates pro-caspase 3 to caspase-3 [14]. The activated caspases cleave cellular proteins (e.g. proteins of the cytoskeleton) and via caspase-activated DNAse (CAD) also chromatin. As a consequence, a typical sequence of morphological and biochemical degradation steps sets in. If the DNA of apoptotic human cells is being analysed by gel electrophoresis, a typical ladder pattern of fragmented chromosomes can be observed. The DNA fragmentation can be reliably monitored and quantified by flow cytometry.

We had found a pronounced cytotoxic effect of some alkaloids on trypanosomes [5]. Therefore, in view of the proapoptotic activity of alkaloids in human tumour cells $[6,10]$ the question to be answered in this communication was, whether programmed cell death (PCD) can be induced in trypanosomes and whether it is also responsible for cell death in $T$. brucei treated with cytotoxic alkaloids. For comparison we have analysed the initiation of apoptosis by the same alkaloids in a human leukemia cell line, Jurkat APO-S, which expresses CD95.

\section{Results and Discussion}

\section{Induction of apoptosis in trypanosomes and leukemia cells (Jurkat APO-S)}

We have selected a series of alkaloids belonging to several structural types. Most of them had been studied before and their cytotoxicity in trypanosomes and human HL60 cells had been determined [5, 6]. In this project, we have used a strain of T. b. brucei TC221 and Jurkat APO-S human leukemia cells for comparison, in order to find out whether cytotoxicity is due to apoptosis.

In a first set of experiments, known substances that can induce apoptosis, such as staurosporine and those that can change the membrane potential of mitochondria, such as carbonylcyanide Mchlorophenyl hydrazone (CCCP) and valinomycin, were studied as positive controls. Staurosporine induced a significant DNA fragmentation in HL60 cells [6] and in trypanosomes (Table 1). As can be seen from Table 1, CCCP and valinomycin significantly induced a change in membrane potential, both in Jurkat cells and in trypanosomes. These results indicate that programmed cell death can be initiated also in trypanosomes.

The main experiment included 55 alkaloids that were tested for their ability to induce DNA fragmentation in trypanosomes (Table 1). If an alkaloid was active, we also studied its ability to induce changes in mitochondrial membrane potential. In addition, we tested Jurkat APO-S cells to see whether the effects were similar in leukemia cells as in trypanosomes. About 28 alkaloids induced apoptosis at a concentration of $100 \mu \mathrm{M}$ in T. brucei. For 14 alkaloids the $\mathrm{EC}_{50}$ values were below 100 $\mu \mathrm{M}$ : quinine, berberine, chelerythrine, emetine, sanguinarine, ajmalicine, ergotamine, harmine, vinblastine, vincristine, colchicine, chaconine, demissidine and veratridine. Especially active in $T$. brucei $\left(\mathrm{EC}_{50}\right.$ below $\left.10 \mu \mathrm{M}\right)$ were chelerythrine, emetine, sanguinarine, and chaconine (Table 2). These alkaloids apparently induce PCD in trypanosomes. 
Table 1. Induction of apoptosis in Trypanosoma b. brucei and in Jurkat APO-S cells.

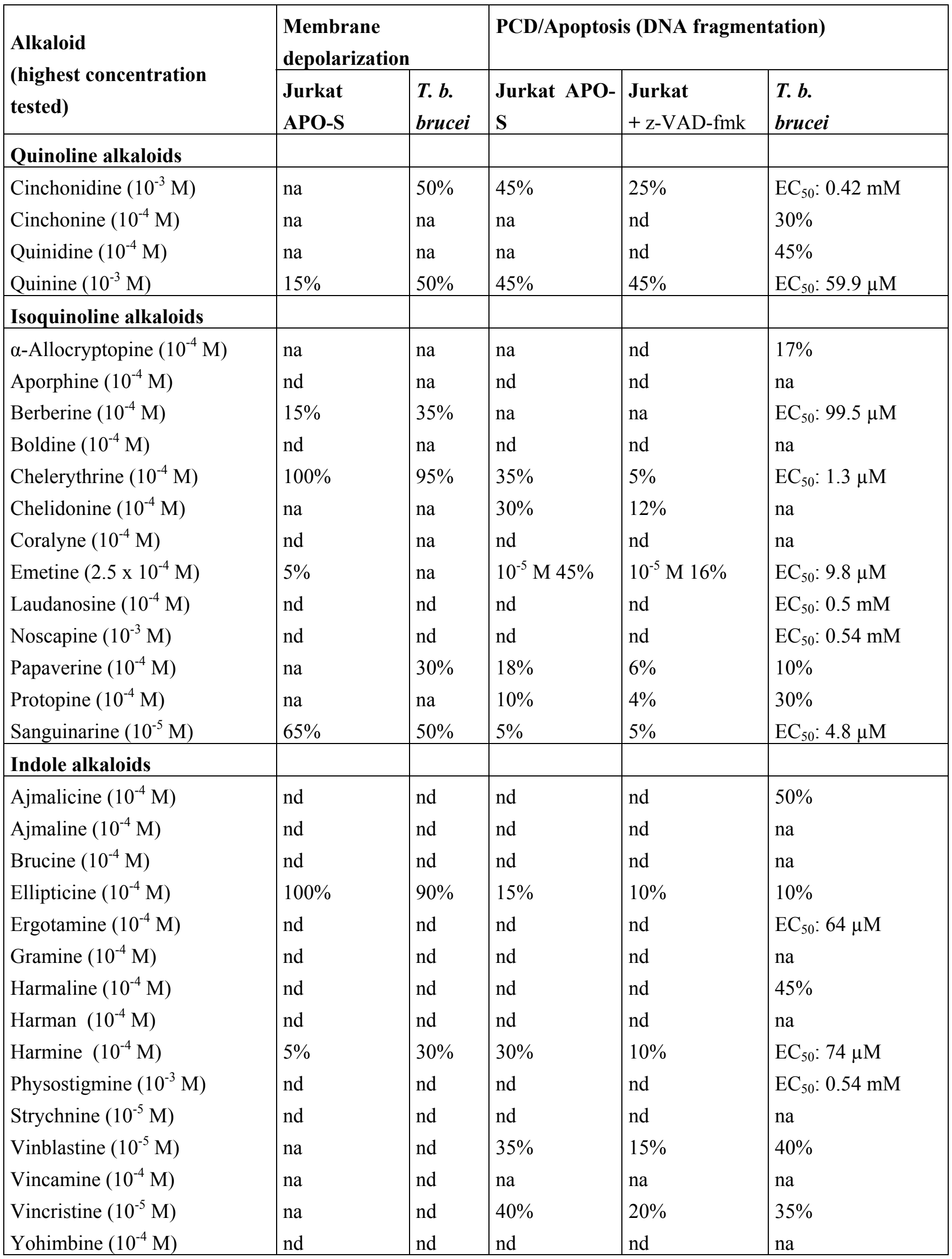


Table 1. Cont.

\begin{tabular}{|c|c|c|c|c|c|}
\hline \multicolumn{6}{|l|}{ Steroidal alkaloids } \\
\hline$\alpha$-Chaconine $\left(10^{-5} \mathrm{M}\right)$ & nd & nd & nd & nd & $\mathrm{EC}_{50}: 2.4 \mu \mathrm{M}$ \\
\hline Demissidine $\left(10^{-4} \mathrm{M}\right)$ & nd & nd & nd & nd & $\mathrm{EC}_{50}: 14 \mu \mathrm{M}$ \\
\hline$\alpha$-Solanine $\left(10^{-5} \mathrm{M}\right)$ & na & na & na & nd & $\mathrm{EC}_{50}: 8.5 \mathrm{mM}$ \\
\hline Veratridine $\left(10^{-4} \mathrm{M}\right)$ & nd & nd & nd & nd & $\mathrm{EC}_{50}: 43 \mu \mathrm{M}$ \\
\hline \multicolumn{6}{|l|}{ Piperidine alkaloids } \\
\hline Arecoline $\left(10^{-3} \mathrm{M}\right)$ & nd & nd & nd & nd & $45 \%$ \\
\hline Coniine $\left(10^{-4} \mathrm{M}\right)$ & nd & nd & nd & nd & na \\
\hline Lobeline $\left(10^{-4} \mathrm{M}\right)$ & nd & nd & nd & nd & na \\
\hline Piperine $\left(10^{-3} \mathrm{M}\right)$ & $50 \%$ & $40 \%$ & $30 \%$ & $5 \%$ & $\mathrm{EC}_{50}: 0.57 \mathrm{mM}$ \\
\hline Pseudopellerine $\left(10^{-3} \mathrm{M}\right)$ & nd & nd & nd & nd & na \\
\hline \multicolumn{6}{|l|}{ Purine alkaloids } \\
\hline Caffeine $\left(10^{-4} \mathrm{M}\right)$ & nd & nd & nd & nd & na \\
\hline Theobromine $\left(10^{-4} \mathrm{M}\right)$ & nd & nd & nd & nd & na \\
\hline Theophylline $\left(10^{-4} \mathrm{M}\right)$ & nd & nd & nd & nd & na \\
\hline \multicolumn{6}{|l|}{ Tropane alkaloids } \\
\hline Hyoscyamine $\left(10^{-3} \mathrm{M}\right)$ & nd & nd & nd & nd & $32 \%$ \\
\hline Methylscopolamine $\left(10^{-3} \mathrm{M}\right)$ & nd & nd & nd & nd & na \\
\hline Tropine $\left(10^{-3} \mathrm{M}\right)$ & nd & nd & nd & nd & na \\
\hline \multicolumn{6}{|l|}{ Quinolizidine alkaloids } \\
\hline Cytisine $\left(10^{-4} \mathrm{M}\right)$ & nd & nd & nd & nd & na \\
\hline Lupanine $\left(10^{-3} \mathrm{M}\right)$ & nd & nd & nd & nd & na \\
\hline Sparteine $\left(10^{-3} \mathrm{M}\right)$ & nd & nd & nd & nd & na \\
\hline \multicolumn{6}{|l|}{ Other alkaloids } \\
\hline Aconitine $\left(10^{-5} \mathrm{M}\right)$ & nd & nd & nd & nd & na \\
\hline Capsaicine $\left(10^{-5} \mathrm{M}\right)$ & nd & nd & nd & nd & na \\
\hline Colchicine $\left(10^{-4} \mathrm{M}\right)$ & na & $40 \%$ & $50 \%$ & $22 \%$ & $50 \%$ \\
\hline Ephedrine $\left(10^{-3} \mathrm{M}\right)$ & nd & nd & nd & nd & na \\
\hline Nicotine $\left(10^{-3} \mathrm{M}\right)$ & nd & nd & nd & nd & na \\
\hline \multicolumn{6}{|l|}{ Controls } \\
\hline Actinomycin D $\left(10^{-3} \mathrm{M}\right)$ & nd & nd & $35 \%$ & $12 \%$ & nd \\
\hline $\operatorname{CCCP}\left(10^{-5} \mathrm{M}\right)$ & $60 \%$ & $50 \%$ & nd & nd & $\mathrm{EC}_{50}: 30 \mu \mathrm{M}$ \\
\hline Staurosporine $\left(5 \times 10^{-5} \mathrm{M}\right)$ & nd & nd & nd & nd & $\mathrm{EC}_{50}: 29 \mathrm{nM}$ \\
\hline Valinomycin $\left(10^{-5} \mathrm{M}\right)$ & $40 \%$ & $100 \%$ & $55 \%$ & $40 \%$ & $40 \%$ \\
\hline
\end{tabular}

DNA fragmentation and the change in membrane potential of mitochondrial membranes were determined as a measure for PCD and apoptosis. For alkaloids, which induce apoptosis in human leukaemia cells, we have assayed the participation of caspase 3 by applying the caspase 3 inhibitor $\mathrm{z}$-VAD-fmk (trypanosomes do not have caspases); na = not active; $\mathrm{nd}=$ not determined. 
Not all alkaloids induced PCD; most tropane, quinolizidine, piperine, pyridine, purine, steroidal, and diterpene alkaloids were not active up to a concentration of $100 \mu \mathrm{M}$ (Table 1 and [6]). In general, alkaloids, which were found to be highly cytotoxic for trypanosomes also induced significant PCD (Table 2) in trypanosomes and in Jurkat cells. Some alkaloids, such as sanguinarine or emetine, showed a similar high toxicity in trypanosomes as in human leukemia cells, which would make them rather unsuitable for clinical applications. In other instances - quinine, ergotamine, berberine, cinchonidine, quinidine and cinchonine - the toxicity was substantially higher in trypanosomes than in leukemia cells. These alkaloids represent interesting lead structures for potential antitrypanosomal drugs, but we need further in vivo experiments showing their bioavailability. Most drugs, which are presently in use, such as suramin, are effective on blood stage forms but not active against brain infections. There is pharmacological evidence that the Cinchona alkaloids and ergot alkaloids can cross the blood brain barrier [8]. Interestingly, the Cinchona-alkaloids quinine have been used successfully against malaria parasites (Plasmodium) [3, 7, 23].

Table 2. Comparison between T. brucei and human leukemia cells (Jurkat APO-S, HL60).

Data for cytotoxicity for T. brucei came from [5], those for HL60 from [5 and 6].

\begin{tabular}{|c|c|c|c|c|c|}
\hline \multirow[b]{2}{*}{ Alkaloid } & \multicolumn{3}{|c|}{ Induction of apoptosis/PCD } & \multicolumn{2}{|c|}{ Cytotoxicity } \\
\hline & T. brucei & $\begin{array}{l}\text { Jurkat APO-S } \\
100 \mu \mathrm{M}\end{array}$ & $\begin{array}{l}\text { HL60 } \\
\text { MAC }\end{array}$ & T. brucei & HL60 \\
\hline Chelerythrine & $\mathrm{EC}_{50}: 1.3 \mu \mathrm{M}$ & +++ & $1 \mu \mathrm{M}$ & nd & nd \\
\hline Chaconine & $\mathrm{EC}_{50}: 2.4 \mu \mathrm{M}$ & nd & na & nd & nd \\
\hline Sanguinarine & $\mathrm{EC}_{50}: 4.8 \mu \mathrm{M}$ & + & $5 \mu \mathrm{M}$ & $\mathrm{EC}_{50}: 1.9 \mu \mathrm{M}$ & $\mathrm{EC}_{50}: 1.4 \mu \mathrm{M}$ \\
\hline Emetine & $\mathrm{EC}_{50}: 9.8 \mu \mathrm{M}$ & +++ & $0.5 \mu \mathrm{M}$ & $\mathrm{EC}_{50}: 0.04 \mu \mathrm{M}$ & $\mathrm{EC}_{50}: 0.09 \mu \mathrm{M}$ \\
\hline Demissidine & $\mathrm{EC}_{50}: 14 \mu \mathrm{M}$ & nd & nd & nd & nd \\
\hline Veratridine & $\mathrm{EC}_{50}: 43 \mu \mathrm{M}$ & nd & na & nd & nd \\
\hline Quinine & $\mathrm{EC}_{50}: 59.9 \mu \mathrm{M}$ & ++ & $500 \mu \mathrm{M}$ & $\mathrm{EC}_{50}: 4.9 \mu \mathrm{M}$ & $\mathrm{EC}_{50}: 126 \mu \mathrm{M}$ \\
\hline Ergotamine & $\mathrm{EC}_{50}: 64 \mu \mathrm{M}$ & nd & $50 \mu \mathrm{M}$ & $\mathrm{EC}_{50}: 3.2 \mu \mathrm{M}$ & $\mathrm{EC}_{50}: 32 \mu \mathrm{M}$ \\
\hline Harmine & $\mathrm{EC}_{50}: 74 \mu \mathrm{M}$ & ++ & $100 \mu \mathrm{M}$ & nd & nd \\
\hline Berberine & $\mathrm{EC}_{50}: 99.5 \mu \mathrm{M}$ & na & $100 \mu \mathrm{M}$ & $\mathrm{EC}_{50}: 0.53 \mu \mathrm{M}$ & $\mathrm{EC}_{50}: 27 \mu \mathrm{M}$ \\
\hline Cinchonidine & $\mathrm{EC}_{50}: 420 \mu \mathrm{M}$ & ++ & $100 \mu \mathrm{M}$ & $\mathrm{EC}_{50}: 7.1 \mu \mathrm{M}$ & $\mathrm{EC}_{50}: 169 \mu \mathrm{M}$ \\
\hline Laudanosine & $\mathrm{EC}_{50}: 500 \mu \mathrm{M}$ & nd & na & nd & nd \\
\hline Noscapine & $\mathrm{EC}_{50}: 540 \mu \mathrm{M}$ & nd & $50 \mu \mathrm{M}$ & nd & nd \\
\hline Piperine & $\mathrm{EC}_{50}: 570 \mu \mathrm{M}$ & ++ & $100 \mu \mathrm{M}$ & $\mathrm{EC}_{50}:>100 \mu \mathrm{M}$ & nd \\
\hline Vinblastine & $10^{-5} \mathrm{M}: 40 \%$ & +++ & $5 \mathrm{nM}$ & nd & nd \\
\hline Vincristine & $10^{-5} \mathrm{M}: 35 \%$ & +++ & $5 \mathrm{nM}$ & nd & nd \\
\hline Colchicine & $10^{-4} \mathrm{M}: 50 \%$ & +++ & $0.1 \mu \mathrm{M}$ & $\mathrm{EC}_{50}: 21 \mu \mathrm{M}$ & nd \\
\hline Ajmalicine & $10^{-4} \mathrm{M}: 50 \%$ & nd & $50 \mu \mathrm{M}$ & nd & nd \\
\hline Harmaline & $10^{-4} \mathrm{M}: 45 \%$ & nd & na & $\mathrm{EC}_{50}: 30 \mu \mathrm{M}$ & nd \\
\hline Quinidine & $10^{-4} \mathrm{M}: 45 \%$ & na & na & $\mathrm{EC}_{50}: 0.7 \mu \mathrm{M}$ & $\mathrm{EC}_{50}: 400 \mu \mathrm{M}$ \\
\hline Cinchonine & $10^{-4} \mathrm{M}: 30 \%$ & na & na & $\mathrm{EC}_{50}: 1.2 \mu \mathrm{M}$ & $\mathrm{EC}_{50}: 382 \mu \mathrm{M}$ \\
\hline Ellipticine & $10^{-4} \mathrm{M}: 10 \%$ & ++ & $5 \mu \mathrm{M}$ & nd & nd \\
\hline
\end{tabular}

Jurkat cells: $+=<10 \%$ apoptosis at $10^{-4} \mathrm{M} ;++=10-30 \%,+++=>30 \%$. MAC $=$ minimal apoptotic concentration 
The active alkaloids have in common that they affect central molecular targets in cells (as shown in previous studies [7-10]): they intercalate DNA, and in consequence inhibit DNA and RNA polymerase, topoisomerases, and even ribosomal protein biosynthesis, or bind to tubulin/microtubules, thus acting as spindle poisons or to disturb membrane integrity (Table 3 ).

Table 3. Molecular targets of apoptotic alkaloids [7-10, 15].

\begin{tabular}{|l|l|l|l|l|l|}
\hline Alkaloid & $\begin{array}{l}\text { Disturbance of } \\
\text { Membrane } \\
\text { fluidity }\end{array}$ & $\begin{array}{l}\text { DNA } \\
\text { intercalation }\end{array}$ & $\begin{array}{l}\text { Protein } \\
\text { biosynthesis } \\
\text { inhibition }\end{array}$ & $\begin{array}{l}\text { Microtubul } \\
\text { inhibition }\end{array}$ & Neurotoxins \\
\hline Berberine & na & ++ & ++ & na & + \\
Chaconine & +++ & nd & + & na \\
Cinchonidine & na & + & ++ & na \\
Cinchonine & na & + & + & na \\
Colchicine & + & nd & na & +++ & + \\
Demissidine & +++ & nd & nd & nd \\
Emetine & na & + & ++++ & na & + \\
Ergotamine & na & ++ & ++ & nd & + \\
Harmine & + & ++ & nd & +++ \\
Quinidine & + & + & na & +++ \\
Quinine & na & + & na & + \\
Sanguinarine & + & ++ & nd & + \\
Vinblastine & nd & nd & nd & ++ \\
Vincristine & nd & ++ & + \\
\hline
\end{tabular}

na $=$ not active, $n d=$ not determined

DNA damage, which can also be caused by intercalating compounds, alkylation or gammairradiation and other signals, can stimulate the tumor suppressor gene p53 in human cells. In consequence, Apaf-1 becomes activated, triggering apoptosis. P53 is a stress sensor that is modified by posttranslational modifications. Activated p53 reacts as a transcription factor for pro-apoptotic proteins, including BAX, and death receptors (CD95, TRAIL).

Some of the cytotoxic and PCD-inducing alkaloids (Table 1) had also been found to be trypanocidal in other studies, mainly against T. cruzi: steroidal alkaloids [20, 32], piperine [21, 33], cinchonidine [22], cinchonine [23], berberine [24, 25], emetine [25 -27], sanguinarine [28], ellipticine [29], harmaline [25, 30], harmine [24, 25, 28, 30], vinblastine [31], vincristine [21], and colchicine [34].

Programmed cell death is apparently not restricted to metazoan animals, but can also occur in a related fashion in protozoa; it has been detected in Trypanosoma cruzi and T. brucei [16, 17, 35, 36]. In T. brucei for example, prostaglandin D, which inhibits growth of bloodstream forms, induces PCD with characteristic apoptosis features (maintenance of plasma membrane integrity, exposure of phosphatidylserine, loss of mitochondrial membrane potential, condensation of nuclear chromatin and DNA fragmentation) [35]. However, protozoa do not have caspases, they apparently lack the receptors of corresponding signaling pathways and do not form an apoptosome; therefore, the classical apoptosis mechanism cannot work in protozoa [36]. Published data indicate that apoptosis may occur in human cells in the absence of caspases [37-39]. To our knowledge, our report is the first to show that several 
of the trypanocidal alkaloids induce apoptosis-like cell death in $T$. brucei (albeit via unknown mechanisms) When searching for new drugs with antitrypanosomal activities, those secondary metabolites with apoptotic properties in metazoan cells could therefore be of major interest [10].

\section{Experimental}

\section{Cell line and culture conditions}

Jurkat APO-S derives from a human T cell leukemia; it is sensitive to apoptosis through CD95 expression. Jurkat-APO-S cells were maintained in RPMI 1640 medium without phenol red and L-glutamine (Gibco BRL, Life Technologies GmbH, Karlsruhe, Germany). The medium was supplemented with 10\% inactivated fetal calf serum (Seromed ${ }^{\circledR}$, Biochrom KG, Berlin, Germany), 100 units $/ \mathrm{ml}$ penicillin, $100 \mu \mathrm{g} / \mathrm{mL}$ streptomycin (BioWhittaker, Walkersville, MD, USA) and 1\% L-glutamine. Suspension-cultured cells were grown in $25 \mathrm{~mL}$ or $75 \mathrm{~mL}$ culture flasks (Cellstar, Greiner Labortechnik GmbH, Frickenhausen, Germany), incubated at $37{ }^{\circ} \mathrm{C}$ with $5 \% \mathrm{CO}_{2}$ and diluted every 2 - 3 days to a final concentration of ca. 1 x $10^{5}$ cells $/ \mathrm{mL}$. Cell counts were performed with a Neubauer-count chamber, and general viability was assessed by Trypan blue exclusion.

\section{Culture of Trypanosoma b. brucei}

Trypanosoma b. brucei TC221 (which came from D. Steverding, Hygiene-Institut, Heidelberg University) were cultivated in culture flasks with Baltz medium [18] at $37{ }^{\circ} \mathrm{C}$ and $5 \% \mathrm{CO}_{2}$. Blood stream forms multiply ten-fold in suspension culture every $25 \mathrm{~h}$, cultures were diluted every 2 to 3 days about 100-fold with fresh medium. A maximal density of $2 \times 10^{6}$ cells was not exceeded.

\section{Tested substances}

Alkaloids were either obtained commercially or had been isolated in our laboratory. There purity was usually higher than $98 \%$. The origin of tested compounds has been documented in $[5,6,15]$. Compounds were dissolved in aqua bidest, DMSO or ethanol to final concentrations of $10^{-1}$ to $10^{-3} \mathrm{M}$. After a 1:10-dilution with RPMI medium the mixture was sterilized by filtration ( $0.2 \mu \mathrm{m}$ diameter). Further 1:10-dilutions were made with sterile medium containing 10\% of the solvent agent to ensure an equal amount of the solvent in the tests, about $1 \%$.

\section{Induction of apoptosis}

In order to induce apoptosis in Jurkat cells were seeded into 24-well plates (Gibco BRL), each well was filled with cell culture medium $(1 \mathrm{~mL})$. The cell number used in each experiment depended on the incubation time. Cells or trypanosomes were seeded into the wells with a concentration of $5 \times 10^{5}$ or 1 $2 \times 10^{5}$ cells $/ \mathrm{mL}$, respectively. Compounds were given to the cells in various concentrations, with 10 to $5 \mu \mathrm{L} /$ well. Untreated cultures and cultures treated with medium containing $10 \%$ solvent were used for 
control measurements. The caspase-3 inhibitor z-VAD-fmk was added 30 min before the addition of test compounds. Experiments were run for $24 \mathrm{~h}$.

\section{Analysis of cell death}

Apoptosis was examined by cell morphology (fluorescence microscopy), DNA gel electrophoresis, but mainly by flow cytometry. Also the activity of caspase 3 (including the caspase 3 inhibitor z-VADfmk) and membrane potential were determined using actinomycin D, CCCP (carbonylcyanide Mchlorophenyl hydrazone), staurosporine, and valinomycin as positive controls.

\section{Flow cytometry analysis:}

Treated or untreated cell culture $(1 \mathrm{~mL})$ was harvested from the 24-well plates and centrifuged for $10 \mathrm{~min}$ at $4{ }^{\circ} \mathrm{C}$ and $400 \mathrm{x}$. After a washing step with HBSS (Hank's balanced salt solution without $\mathrm{Mg}^{2+} / \mathrm{Ca}^{2+}, 1 \mathrm{~mL}$, Gibco BRL) cells were incubated with HBSS $(900 \mu \mathrm{L})$ and PC-buffer $\left(\mathrm{Na}_{2} \mathrm{HPO}_{4} 0.2\right.$ $\mathrm{M}$, citric acid $0.1 \mathrm{M}, \mathrm{pH} 7.8,300 \mu \mathrm{L}$ ) for $5 \mathrm{~min}$, then centrifuged as described above. Cells were fixed with $1 \mathrm{ml}$ ice-cold $70 \%$ ethanol and incubated at $-20{ }^{\circ} \mathrm{C}$ for at least $2 \mathrm{~h}$. Apoptotic cells were detected using propidium iodide (PI) staining [19]. Cells in $70 \%$ ethanol were centrifuged for 10 min at $4{ }^{\circ} \mathrm{C}$ and $400 \mathrm{x} g$, washed once with HBSS ( $1 \mathrm{~mL}$ ), and incubated with PI staining solution (containing 0.05 $\mathrm{mg} \mathrm{PI} / \mathrm{ml} \mathrm{HBSS}$ and $0.5 \mathrm{mg}$ RNAse/mL HBSS, $200 \mu \mathrm{L}$ ) for at least $30 \mathrm{~min}$ before measurement with the FACScan analyzer. Experiments were performed in triplicate and repeated at least three times.

\section{Determination of mitochondrial membrane potential}

An early step in the intrinsic apoptotic cascade is a reduction of the mitochondrial membrane potential. The change in membrane potential can be determined using a fluorescent dye, JC- 1 . If the membrane potential is between -170 and $-220 \mathrm{mV}$, than JC-1 produces a red fluorescence. If the potential is lowered a green fluorescence can be detected. These changes can be recorded by the FACSan analyzer. The membrane potential was determined, 2, 4, 6 and $8 \mathrm{~h}$ after the application of the alkaloids. Treated or untreated cell culture $(1 \mathrm{~mL})$ was harvested from the 24 -well plates and centrifuged for $10 \mathrm{~min}$ at $4{ }^{\circ} \mathrm{C}$ and $400 \mathrm{x} \mathrm{g}$ and washed with $\mathrm{HBSS}$ (without $\mathrm{Ca}^{2+}, \mathrm{Mg}^{2+}$, phenol red, $500 \mu \mathrm{L})$. The sediment was stained with JC-1 $(1 \mu \mathrm{g} / \mathrm{mL})$. After $15 \mathrm{~min}$ incubation in the dark a $37^{\circ} \mathrm{C}$, HBSS $(400 \mu \mathrm{L})$ was added and the culture subjected to FACS measurements, by recording red or green fluorescence. Experiments were performed in triplicate and repeated at least three times.

\section{Data analysis}

A total of 10,000 cells per sample was analyzed by FACScan and Cell Quest software (Becton Dickinson, Heidelberg, Germany) and with WinMDI software (version 2.7, Microsoft Corp.). SigmaPlot 8.0 was used to calculate $\mathrm{EC}_{50}$ values. 


\section{Acknowledgements}

We thank Klaus Hexel and the people from the Tumor Immunology Department at the Deutsches Krebsforschungszentrum (DKFZ), Heidelberg for their generous support to use their FACScan. Dr. V. Umansky kindly provided the Jurkat APO-S cells. The Deutsche Forschungsgemeinschaft supported this project through a fellowship (to V.R.) (Graduiertenkolleg 388: Biotechnologie). Special thanks to Dr. Dietmar Steverding for helpful comments and fruitful years of collaboration.

\section{References}

1. Molyneux, D.H. Current public health status of trypanosomiases and leishmaniases. In Trypanosomiasis and leishmaniasis: biology and control; Hide G, Mottram, J.C., Coombs, G.H., Holmes, P.H., Eds; CAB International: Wallington, 1997; pp. 39-50.

2. Kristjanson, P.M.; Swallow, B.M.; Rowlands, G.J.; Kruska, R.L.; de Leeuw, P.N. Measuring the costs of African animal trypanosomiasis, the potential benefits of control and returns to research. Agr. Syst. 1999, 59, 79-98.

3. Croft, S.L. The current status of antiparasitic chemotherapy. Parasitology 1997 (supplement), 114, 3-15.

4. Ross, C.A.; Sutherland, D.V. Drug resistance in trypanosomatids. In Trypanosomiasis and leishmaniasis: biology and control; Hide G, Mottram, J.C., Coombs, G.H., Holmes, P.H., Eds; CAB International: Wallington, 1997; pp. 259-269.

5. Merschjohann, K.; Sporer, F.; Steverding, D.; Wink, M. In vitro effects of alkaloids on bloodstream forms of Trypanosoma brucei and T. congolense. Planta Med. 2001, 67, 623-627.

6. Rosenkranz, V.; Wink, M. Induction of apoptosis by alkaloids, non-protein amino acids, and cardiac glycosides in human promyelotic HL-60 cels. Z. Naturforsch. 2007, 62c, 458-466.

7. Wink, M. Allelochemical properties and the raison d'être of alkaloids. In The Alkaloids, G. Cordell, Ed.; Academic Press: Orlando, FL, 1993; Vol. 43, pp. 1-118.

8. Wink, M. Interference of alkaloids with neuroreceptors and ion channels. In Bioactive natural products; Atta-Ur-Rahman, Ed.; Elsevier: Amsterdam, New York; 2000; Vol. 11, pp. 3-129.

9. Wink, M.; Schimmer, O. Modes of action of defensive secondary metabolites. In Function of Plant secondary metabolites and their exploitation in biotechnology; Wink, M., Ed.; Annual Plant Reviews; Sheffield Academic Press: Sheffield, 1999; Vol. 3, pp. 17-133.

10. Wink, M. Molecular modes of action of cytotoxic alkaloids - From DNA intercalation, spindle poisoning, topoisomerase inhibition to apoptosis and multiple drug resistance. In The Alkaloids; Cordell, G., Ed.; Elsevier: Amsterdam, New York; 2007; Vol. 64, pp. 1-48.

11. Roberts, M.F.; Wink, M. Alkaloids: Biochemistry, ecology and medicinal applications; Plenum: New York, 1998.

12. Kerr; J.B.; Wyllie, A.H.; Currie, A.R. Apoptosis: a basic biological phenomenon with wide-ranging complication in tissue kinetics. Br. J. Cancer 1972; 26, 239-57

13. Krammer, H. CD95(APO-1/Fas)-mediated apoptosis: live and let die. Adv. Immunol. 1999, 71, 163-210. 
14. Zamzami, N.; Kroemer, G. The mitochondrion in apoptosis: how Pandora's box opens. Nature Rev. Mol. Cell Biol. 2001, 2, 67-71.

15. Wink, M.; Schmeller, T.; Latz-Brüning, B. Modes of action of allelochemical alkaloids: Interaction with neuroreceptors, DNA and other molecular targets. J. Chem. Ecol. 1998, 24, 1881-1937.

16. Ameisen, J.-C.; Idziorek, T.; Billaut-Multo, O.; Loyens, M.; Yissier, J.-P.; Potentier, A; Ouai, A. Apoptosis in a unicellular eukaryote (Trypanosoma cruzi): Implications for the evolutionary origin and role of programmed cell death in the control of cell proliferation, differentiation and survival. Parasitol. Today 1996, 12, 49.

17. Welburn, S.C.; Dale, C.; Ellis, D.; Beecroft, R.; Pearson, T.W. Apoptosis in procyclic Trypanosoma brucei rhodesiense in vitro. Cell Death Differ. 1996, 3, 229-36.

18. Baltz, T.; Baltz, C.; Giroud, C.; Crockett, J. Cultivation in a semi-defined medium of animal infective forms of Trypansoma brucei, T. equiperdum, T. evansi, T. rhodesiense and $T$. gambiense. EMBO J. 1985, 4, 1273-1277.

19. Nicoletti, I.G.; Migliorati, M.C.; Pagliacci, F.; Grignani, F.; Riccardi, C. A rapid and simple method for measuring thymocyte apoptosis by propidium iodide staining and flow cytometry. $J$. Immunol. Meth. 1991, 139, 271-279.

20. Hall, C.A.; Hobby, T.; Cipollini, M. Efficacy and mechanisms of alpha-solasonine-and alphasolamargine-induced cytolysis on two strains of Trypanosoma cruzi. J. Chem. Ecol. 2006, 32, 2405-16.

21. Freire-de-Lima, L.; Ribeiro, T.S.; Rocha, G.M.; Brandão, B.A.; Romeiro, A.; MendonçaPreviato, L.; Previato, J.O.; de Lima, M.E.; de Carvalho, T.M.; Heise, N. The toxic effects of piperine against Trypanosoma cruzi: ultrastructural alterations and reversible blockage of cytokinesis in epimastigote forms. Parasitol. Res. 2008, 102, 1059-67.

22. Ruiz-Mesia, L.; Ruiz-Mesia, W.; Reina, M.; Martinez-Diaz, R.; de Ines, C.; Guadano, A.; Gonzalez-Coloma, A. Bioactive cinchona alkaloids from Remijia peruviana. J. Agric. Food Chem. 2005, 53, 1921-1926.

23. Kayser, O.; Kiderlen, A, F.; Croft, S.L. Natural products as potential antiparasitic drugs. Stud. Nat. Prod. Chem. 2002, 26G, 779-848.

24. Abe, F.; Nagafuji, S.; Okabe, H.; Akahane, H.; Estrada-Muniz, E.; Huerta-Reyes, M.; ReyesChilpa, R. Trypanocidal constituents in plants 3. Leaves of Garcinia intermedia and heartwood of Calophyllum brasiliense. Biol. Pharm. Bull. 2004, 27, 141-143.

25. Cavin, J. C.; Krassner, S.M.; Rodriguez, E. Plant-derived alkaloids active against Trypanosoma cruzi. J. Ethnopharmacol. 1987, 19, 89-94.

26. Mackey, Z. B.; Baca, A. M.; Mallari, J. P.; Apsel, Beth; S., Anang; H., Elizabeth J.; Chiang, P. K.; Wolff, Brian; G., Kiplin R.; Williams, J.; McKerrow, J. H. Discovery of trypanocidal compounds by whole cell HTS of Trypanosoma brucei. Chem. Biol. Drug Des. 2006, 67, 355363.

27. Konopka, E. A.; Goble, F. C.; Prins, D. A. Emetine and some related compounds in experimental Chagas' disease. Antimicrob. Agents Chemother. 1965, 772-776. 
28. Hopp, K. H.; Cunningham, L. V.; Bromel, M. C.; Schermeister, L. J.; Khalil, S. K. Wahba. In vitro antitrypanosomal activity of certain alkaloids against Trypanosoma lewisi. Lloydia 1976, 39, 375-7.

29. Benard, J.; Nguyen Dat X.; Riou, G. Trypanocide activity of some ellipticine derivatives against Trypanosoma cruzi cultured in vitro. Compt. Rend. Sean.s Acad. Sci. Ser. D: Sci. Nat. 1975, 280, 1177-1180.

30. Rivas, P.; Cassels, B. K.; Morello, A.; Repetto, Y. Effects of some .beta.-carboline alkaloids on intact Trypanosoma cruzi epimastigotes. Comp. Biochem. Physiol. 1999, 122C, 27-31.

31. da Silva, R. A.; Bartholomeu, D. C.; Teixeira, S. M. R. Control mechanisms of tubulin gene expression in Trypanosoma cruzi. Int. J. Parasitol. 2006, 36, 87-96.

32. Chataing, B.; Concepcion, J. L.; Lobaton, R.; Usubillaga, A. Inhibition of Trypanosoma cruzi growth in vitro by Solanum alkaloids. A comparison with ketoconazole. Planta Med. 1998, 64, 31-36.

33. Ribeiro, T. S.; Freire-de-Lima, L.; Previato, J. O.; Mendonca-Previato, L.; Heise, N.; Freire de Lima, M.E.. Toxic effects of natural piperine and its derivatives on epimastigotes and amastigotes of Trypanosoma cruzi. Bioorg. Med. Chem. Lett. 2004, 14, 3555-3558.

34. Astolfi F., S.; Pereira de Almeida, E. R.; Gander, E.S. The influence of hydroxyurea and colchicine on growth and morphology of Trypanosoma cruzi. Acta Trop. 1978, 35, 229-237.

35. Figarella K.; Rawer M.; Uzcategui N. L.; Kubata B. K.; Lauber K.; Madeo F.; Wesselborg S.; Duszenko M. Prostaglandin D2 induces programmed cell death in Trypanosoma brucei bloodstream form. Cell Death Diff. 2006, 13, 1802-1814.

36. Duszenko M.; Figarella K.; Macleod E. T.; Welburn S. C. Death of a trypanosome: a selfish altruism. Trends Parasitol. 2006, 22, 536-542.

37. Jaattela M.; Tschopp J. Caspase-independent cell death in T lymphocytes. Nat. Immunol. 2003, $5,416-423$.

38. Lorenzo H.K.; Susin S. A. Mitochondrial effectors in caspase-independent cell death. FEBS Lett 2004, 557, 14-20.

39. Lockshin R. A.; Zakewri Z. Caspase-independent cell death? Oncogene 2004, 23, 2766-2773.

(C) 2008 by the authors; licensee Molecular Diversity Preservation International, Basel, Switzerland. This article is an open-access article distributed under the terms and conditions of the Creative Commons Attribution license (http://creativecommons.org/licenses/by/3.0/). 